\title{
Current Trends in the International Business Environment
}

\author{
Anura Amarasena \\ Endicott College of International Studies, Woosong University, South Korea
}

Copyright $\bigcirc 2017$ by authors, all rights reserved. Authors agree that this article remains permanently open access under the terms of the Creative Commons Attribution License 4.0 International License

\begin{abstract}
This paper provides a critical review of existing theories on International Business (IB) in order to establish current theoretical direction as the paper argues whether traditional theories of international business (IB) can help explain e-commerce. In order to achieve this objective, the basics of international business and current trends in the international business environment affecting firm internationalisation are addressed. Existing literature is examined in light of the development of the information and communication technologies (ICTs) particularly the Internet and e-commerce. The analysis provides explanations to the question of what extent can the Internet related IB activities be accommodated within the current theories of IB.
\end{abstract}

Keywords International Business (IB), Information and Communication Technologies (ICTs), Internet, Firm Internationalization, Exporting, Born Global

\section{Introduction}

International Business (IB) is described in the literature as a limited and underdeveloped hybrid of various elements borrowed from many related basic disciplines. Due to the continual changing nature of IB and new ways of doing business, the knowledge developed until 1950s carries mainly a historical value. As recent literature on IB suggests that the mode of market entry is the most important decision in IB which determines the ability of the firm to deal with its foreign customers, control the IB process and its resource commitment to the foreign market. The study of international market entry or internationalization of firms has attracted increasing interests in the academic literature is an indication of the importance of this subject.

Though there has been a theoretical development in the literature on IB, the literature has not been consolidated and analysed in the context of the development of the information and communication technologies (ICTs) particularly the Internet and e-commerce. The purpose of this article is to provide a critical review of existing theories on IB in order to establish current theoretical direction. In particular, the analysis provides discussion and explanations to the question of what extent can the Internet related IB activities be accommodated within the current theories of IB.

With the objective of achieving the purpose of this article, the paper is divided into two main sections. The first section provides a review of the vital literature on nine international business theories namely Market imperfection (Ownership advantage), Location specific advantage, Internalisation, Transaction cost, Strategic behaviour approach, Resource based view of the firm (RBV), Eclectic paradigm, the Uppsala internationalisation model (the Stage model) and the Network approach to internationalisation. The review highlights that among the main entry mode theories discussed in this paper, the Eclectic paradigm, the Staged model and the Network approach are prominently used in explaining firm internationalisation.

The subsequent section reviews the literature on the 'born global'. The emerging exporters within the small firm sector and the explanations for their internationalisation are also explored here. A number of factors that seem to contribute to the phenomenon 'born global' are discussed in detail. Finally the conclusion section summarises the major findings based on the analysis and discussions. The paper argues whether traditional theories of international business can help explain e-commerce. This section also suggests some avenues for future research.

\section{International Business}

As defined by Czinkota, Rivoli and Ronkainen (33) international business (IB) consists of dealings that are formulated and conducted across national borders to satisfy the objectives of individuals and firms. However, it varies from export-import trade to licensing, joint ventures, entirely owned subsidiaries, turnkey operations, and management contracts. Boddewyn and Iyer (15) identify international business (IB) as an area of academic interests where a distinction is generally made between the basic disciplines 
such as economics, political science, sociology and psychology, and the professional areas such as marketing and finance, which relate concepts, constructs, models and variables obtained from these disciplines. In this context, IB theory is described in the literature as a limited and underdeveloped hybrid of various elements borrowed from the above basic disciplines. Owing to the continual changing nature of IB and new ways of doing business, the knowledge developed in the 1930s, 1940s and 1950s carries mainly a historical value (15).

Nevertheless, recent literature on IB suggests that the mode of market entry is the most important decision in IB. This determines the ability of the firm to deal with its foreign customers; to control the IB process and its resource commitment to the foreign market $(18,72)$. The large number of studies undertaken on the process of international market entry or internationalisation of firms is an indication of the importance of this subject. Therefore, identifying different market entry modes or methods by which firms do businesses abroad is a way of understanding international business.

\subsection{Market Entry Modes in IB}

A review of literature indicates that there are three alternative market entry modes namely exporting, contracting or licensing and investment $(2,67,114,115,133)$.

A study by Jiang (67) summarised seven theories from previous studies explaining foreign market entry modes. In addition the Uppsala Internationalisation Model and the Network Approach to Internationalisation were introduced to explain market entry modes in IB. The theories that are used in explaining foreign market entry modes are summarised in Table 1.1.

Table 1.1. Theories that explain foreign market entry modes

\begin{tabular}{|l|l|}
\hline \multicolumn{1}{|c|}{ Authors } & \multicolumn{1}{|c|}{ Theories } \\
\hline Hymer (66); Kindleberger (77) & $\begin{array}{l}\text { Market imperfection (Ownership } \\
\text { advantage) theory }\end{array}$ \\
\hline $\begin{array}{l}\text { Franko (52); Stopford and Wells } \\
\text { (120) }\end{array}$ & $\begin{array}{l}\text { Location specific advantage } \\
\text { theory }\end{array}$ \\
\hline $\begin{array}{l}\text { Buckley and Casson (19); } \\
\text { McManus (96) }\end{array}$ & Internalisation theory \\
\hline $\begin{array}{l}\text { Anderson and Gatignon (2); } \\
\text { Buckley and Casson (19); Casson } \\
\text { (23); Caves (23); Erramilli and } \\
\text { Rao (48); Williamson (129,130) }\end{array}$ & Transaction cost theory \\
\hline Harrigan (62) & Strategic behaviour approach \\
\hline $\begin{array}{l}\text { Barney (6); Collis (30); Peteraf } \\
\text { (110); Wernerfelt (125) }\end{array}$ & $\begin{array}{l}\text { Resource based view of the firm } \\
\text { (RBV) }\end{array}$ \\
\hline Dunning (37;40) & Eclectic paradigm \\
\hline Johanson and Vahlne (73) & $\begin{array}{l}\text { The Uppsala Internationalisation } \\
\text { Model }\end{array}$ \\
\hline $\begin{array}{l}\text { Johnson and Mattsson (70); } \\
\text { Sharma and Johanson (19) }\end{array}$ & $\begin{array}{l}\text { The Network Approach to } \\
\text { Internationalisation }\end{array}$ \\
\hline
\end{tabular}

Although the following section provides the introduction of each of these theories, more attention is given, and detailed discussion is undertaken, only of the theories that have gained more acceptances in IB literature over the years.

\subsection{Ownership Advantage Theory}

Ownership advantage theory suggests that a firm that carries a valuable asset which creates a competitive advantage for the firm domestically can strategically use that advantage to enter into foreign markets through Foreign Direct Investment (FDI). In another words, the firm must possess some unique advantage that overcomes the disadvantages of competing with foreign firms on their home markets. Hymer (66) and Kindleberger (77) who established the above theory on Multinational Enterprises (MNEs), explain that these firms carry some transferable ownership advantages of factors such as proprietary technology, privileged access to inputs and control over distribution. These advantages permit them to compete against local firms which operate in imperfect markets. Ozga (107) provides explanation to perfect markets and states that for competition to be perfect there must be a large number of buyers and sellers, the goods they buy and sell must be homogeneous, and the buyers and sellers must have perfect knowledge of the market.

FDI has been interpreted as a firm's response to advantages (91). It appears that the firms that carry advantages invest abroad $(24,66)$. However this theory does not provide explanations to questions such as why a firm would enter a foreign market using FDI strategy without giving considerations to use its ownership advantages for other options such as exporting their products, franchising or licensing strategies.

\subsection{Location Specific Advantage Theory}

This theory focuses on the location specific advantages of the foreign market which are mainly categorised as availability of resources and lack of political obstructions for investments. It explains that it is necessary to have a more advantageous foreign location than the home country of operation for a firm to start its business overseas $(52,120)$. Noticeably countries that have an advantageous resource endowment are sites for inbound FDI (37).

Parry (108) argued that location theory could explain why MNEs emerge. Location theory is of two fold. They are 'supply oriented location theory' and 'demand oriented location theory'. Supply oriented location theory explains that production takes place where the factor costs for production and distribution are the lowest. On the contrary, demand oriented location theory argues that the location of a firm is governed by the location of its market and competitors. Taking into account the two arguments, raw materials, cheap labor, protected and untapped markets, and transportation costs are considered as the four location factors that give rise to the emergence of MNEs. This explanation provided good insights to understand geographical distributions of MNEs $(17,36)$. However it was not sufficient to explain "how it was that foreign owned firms 
could outcompete domestic firms in supplying their own market" (38).

It was observed that much of the research on the role of firm-specific advantages has been undertaken in the context of advanced-country multinationals; specifically U.S. MNCs. Research has found that U.S. firms derive ownership advantages from their size, experience, and technological and marketing superiority. It is suggested that such firms having operated in the most-developed and sophisticated home market, many of them generate unique skills that give them advantage over firms in foreign host locations (46).

\subsection{Internalisation Theory}

As explained by Rugman (116) there is a large volume of foreign direct investment and international production by the multinational enterprise (MNE), an activity which cannot be easily explained. It appears that a large literature is available to offer explanations of the phenomenon of foreign direct investment (FDI) and the reasons for international production by the MNE. Internalisation serves to determine the reasons for the foreign production and sales of the MNE. The theory of internalization assumes that MNEs posses a firm-specific advantage in their home market which can be in the form of internally developed, intangible assets that give the firm some superior production, marketing and management knowledge.

This theory was introduced to explain the growth of MNEs and as to why such firms need to consider foreign direct investment (FDI). Internalisation encourages such firms to invest when savings can be made in terms of transaction costs. It appears that Internalization theory addresses the question of why firms chose FDI over the other two possibilities discussed above. This theory is heavily relying on the concept of transaction costs. Transaction costs are the costs of entering into a transaction. They are the costs related to negotiating, monitoring and entering a contract. A firm has the option whether to have its own factory overseas or to contract to with a foreign firm to run its operations. Internalization theory explains that FDI is appropriate to occur for its international production to be internalized within the firm when the costs of negotiating, monitoring and enforcing a contract with a second firm are high. On the contrary, when transaction costs are low, firms are more likely to contract with other firms by licensing or franchising their business operations. Thus the advantage of internalisation is that the firm must benefit more from undertaking the foreign business on their own than from enforcing a contract with other firms to provide the service. The theory states that these internalisation advantages can be gained through a number of ways, such as knowledge-related intangible assets $(19,96)$. Later Dunning (40) utilized this theory in developing the eclectic paradigm which combines location specific advantage, ownership advantage and internalisation advantage to form a unified theory of FDI.

\subsection{Transaction Cost Theory}

The transaction cost approach attempts to provide theoretical explanation for the existence of MNEs (117). Transaction costs theory proposes that the choice between full and partial ownership will depend on the costs and benefits of sharing ownership relative to those of full ownership (63). Williamson $(129,130)$ proposed the transaction cost theory to explain the motivations and choice of joint ventures of MNEs which consider cost minimization. As explained by Kogut (80) a joint venture occurs when two or more firms pool a portion of their resources within a common legal organisation. The theory explains these firms conduct business in the manner that could bring down the total cost of production and transaction costs.

The transaction cost approach considers the transaction as the basic unit of analysis. Therefore an understanding of transaction cost economizing is vital to the study of organizations. It is suggested that economizing can be achieved by assigning transactions to governance structures. The approach applies both to the determination of efficient boundaries and to the organization of internal transactions (130). Kogut (80) further explains the theory and states that transaction costs cover the expenses incurred for writing and enforcing contacts, for bargaining over terms and for deviating from optimal kinds of investments in order to increase dependence on a party or to stabilize relationship, and for administering a transaction. However the transaction cost approach has been criticized for believing that the most efficient institutional form will survive (35).

\subsection{Strategic Behaviour Approach}

This is another way of explaining the use of joint ventures based on strategic behaviour that can lead the firm to competitiveness. In contrast to the transaction cost theory, strategic behaviour theory suggests firms conduct business in the manner which provides maximum profits by means of improving its competitiveness. Thus, the two theories are considered as substitutes to the decision of conducting joint ventures $(62,80)$.

Harrigan (62) provides explanations for companies to overcome the entry and exit barriers that hamper strategic flexibility, timely use of joint ventures to cope with the uncertainties and the management of change. Strategic flexibility is introduced as a way to expand the responsiveness of companies to new competitive conditions. The explanations include on the shortcomings of vertical integration and developing a framework for better make-or-buy decisions.

The above review indicates some theoretical explanations to various forms of international investments of firms across national boundaries. These theories provide motives for national firms to go abroad. It appears that every theory has some useful explanation to the international investments of firms. The following analysis on Eclectic Paradigm (OLI) is to observe whether it provides a better framework for a single general theory which encompasses all other theories of MNEs. 


\subsection{Eclectic Paradigm}

As a response to the growing interests in MNEs and their role in international production in the economies around the world, the eclectic paradigm was first introduced by John Dunning in 1976 who melds the views of the theories on ownership advantage, location specific advantage and internalisation (123). The eclectic paradigm is the pattern of internationalisation of foreign direct investment (FDI) by Multinational Enterprises (MNEs). This theory is the outcome of an attempt to bring together the prevalent main economic and behavioral theories such as the resource-based view of the firm, evolutionary theory, organisational theory and economic strategic theory to explain FDI of MNEs $(37,40,41,42)$. The theory explains that "the extent, pattern and form of IB activity will depend on the juxtaposed behaviour of three sets of advantages" (43).

Dunning $(37,40)$ combined a number of elements from several theories into one eclectic framework to explain the entry mode choice decision of firms. This decision which is also known as "eclectic paradigm" explains that the firm's entry mode decision is influenced by three factors:

- Ownership-specific factors (O) of a firm engaging in value-added activities outside its national boundaries

- Location-specific factors (L) of a market or advantages which are external to the firm

- Internalisation advantages (I) of integrating transactions within the firm $(\mathrm{O}$ advantages will choose to coordinate these advantages with the $\mathrm{L}$ advantages of foreign country) (43).

Brouthers, Brouthers and Werner (16) argue that Dunning's OLI framework provides better ground for predicting an entry mode of a firm than other entry mode theories because the OLI paradigm included essential variables of other theories on entry modes that explain a firm's performance. Brouthers et al. (16) investigated the OLI variables using data from German and Dutch firms investing in Central and Eastern Europe. The focus of this study was the relationship between OLI variables, entry mode selection and managerial satisfaction with the firm's performance. The results indicated that firms which prefer entry modes in the form of joint ventures were the ones which had OLI advantages. However, it was found that the firms with low advantages of OLI prefer less integrated modes such as exporting. Therefore the need to understand how firms achieve superior performance in their international business and the relevance of Dunning's OLI framework was questioned.

As argued by Madhok and Phene (88), the OLI paradigm is considered as a good explanation to the growth of MNEs which was useful in the period it was introduced because that was the era firms started to internationalisation of their businesses. Although the OLI paradigm explained as how MNEs arise, it is questionable whether the paradigm is relevant to the current business environment when a large number of firms have formed their presence overseas and successfully face international competition, create value in the environment where the basis of firm advantage is moving to its ability in creating and managing a knowledge $(20,88)$.

As a result of the development of the Internet and e-commerce, Dunning and Wymbs (43) questioned themselves as "to what extent can the Internet related IB activities be accommodated within the OLI framework of the paradigm" (43) and point to the significance of looking for modifications to the OLI paradigm. This is applicable to the ownership (O), location specific factors (L) and internalisation (I). For example:

a) The strategies of firm expansion are focused in cyber space rather than in the marketplace as a result of the development of the Internet. Thus firms tend to use the market to access resources and capabilities. This is a different approach of the firms competing in the current business environment as previously they had the focus of extending their ownership of these same resource and capabilities (43).

b) The Internet makes the physical location less important for value activities of firms as it makes indistinct the corporate lines between firms and their competitors for any business activity (43).

c) The Electronic Data Interchange (EDI) networks that used to lower transaction costs were affordable only to the large firms before the Internet was developed. With the development of the Internet, EDI-like networks become less expensive and affordable to all businesses. As a result, market access for firms has increased dramatically which led to increased competition (43).

Dunning and Wymbs (43) provide answers to the criticism of Madhok and Phene (88) on the eclectic paradigm of IB activity in the growing e-commerce environment suggesting that the OLI theory that has been used to explain the competitive advantages of MNEs still seems to be valid as the firm's capabilities to acquire sustainable competitive advantages are still applicable. The Internet in this respect assists firms to leverage inimitable ownership advantages which provide the firm with efficiency, asset-creating and value-added activities. In addition, firms look for locations for their greatest possible advantage. Jiang, Christodoulou and Wei (68) and Zhang and Yuk (134) argue that location specific factors such as market size, stage of economic development, host country's incentive policies, labour cost considerations, trade barriers and openness of the economy are good explanations for attracting multinational investments to China. In support of this, $\mathrm{Li}$ and $\mathrm{Li}$ (84) argue that investors with new technology, management and marketing skills are particularly interested in investing in China. However there are counter arguments that large size and low labour cost are not specific to China since such conditions are also available in other developing countries $(68,132)$.

As argued by Cantwell and Narula (21) the eclectic paradigm is still consistent with the theoretical approach of resourced-based view of the firm (RBV). Thus much of the 
criticisms of the eclectic paradigm could be resolved by the explanations of the RBV. For example it is suggested that the intangible assets that are described in RBV of the firm are one of the ownership advantages of the firm (43).

\subsection{Resource Based View (RBV) of the Firm}

The term resource-based view was originally used by Wernerfelt (125) who built on the ideas presented in Penrose's theory of the growth of the firm which looked at firms as a broader set of resources (109). Wernerfelt describes that the competitive advantage of a firm is primarily based in the application of its valuable resources (125). There were a number of articles published in the 1980s which explain the internal resources of the firm, assets and skills as the basis for competitive advantage. The main determinants of a firm's performance and strategy are the internal resources of the firm. It suggests that a competitive advantage of a firm is internally generated from resources that are rare, sustainable and imperfectly imitable $(6,30)$. This theory received broad attention and it was established as a new paradigm in the 1990s. Thereafter, a number of articles have been published on how a firm should deal with its strategically important resources (90).

Firm resources include "all assets, capabilities, organisational processes, firm attributes, information, knowledge, etc. controlled by a firm that enable the firm to conceive of and implement strategies that improve its efficiency and effectiveness" (6). These firm resources are categorised into three types-physical capital, human capital and organisational capital (6). Although all aspects of these resources of a firm are not important, the attributes that contribute to the efficiency and effectiveness of the firm are considered strategic assets or resources $(6,125)$.

The theory has been used in a number of circumstances, including, to test the performance implications of the internal assets of a firm classified as tangible assets, intangible assets and capabilities (9). These assets or attributes have also been classified in various other ways, including physical, intangible and financial resources (27), marketing skills and management capabilities (54), and organisational, social and human capital (131). The combined effect of these assets leads to the uniqueness of any firm (49).

As argued by Clulow, Gerstman and Barry (29) intangible assets are more complex and difficult to define and value than tangible assets. Therefore such complex and specific resources provide barriers to duplication. Intangible assets such as client trust and reputation are difficult to imitate since they result from "accumulated firm-specific activities" (49). Capabilities often display the features of "causal ambiguity", which means difficulty in identifying the resources that are causing the outcomes. Furthermore, "tacitness" occurs in the situations where key resources cannot be clearly identified thereby creating inimitability (29).

According to Barney (6), a firm can have a competitive advantage when it is implementing a value-creating strategy not concurrently being implemented by its current or potential competitors. This advantage can only be sustainable if the firm can resist erosion by competitor activities (11). A sustainable competitive advantage provides a long-term advantage to firms that is not easy to imitate or duplicate. In other words, a competitive advantage becomes a sustainable competitive advantage when all duplication and imitation efforts have ceased and the competitors have not been able to create the same value that the said firm is creating. This sustainable competitive advantage results only from strategic resources or assets (99).

A resource should bear a number of minimum characteristics for it to become a strategic resource and thus to generate income and maintain that income over a period of time $(5,125)$. Barney (8) suggests using a VRIO (Value, Rareness, Inimitability, and Organisation) framework to analyse sources of competitive advantage and sustainable competitive advantage raising the following four questions:

1) "Are the resources and capabilities valuable, enabling the firm to respond to environmental threats and opportunities?

2) Which other firms already possess valuable resources and capabilities?

3) Is there a cost to other firms in obtaining those resources and capabilities?

4) Is the firm organised to exploit the full competitive potential of its resources and capabilities?" (8).

According to the RBV of the firm, business elements which are key resources, such as the Internet, must be valuable, rare and difficult to imitate or substitute $(7,57,128)$. Thus made Barney (8) added a fourth condition: that the element needs to be complementary to the other elements or resources of the firm thereby resulting in synergic effects that would explain improvements in competitive positions that are more than proportionate when the resources operate jointly, compared to when they operate separately. Thus, business resources, likely to become strategic resources, such as Internet, must satisfy the VRIO conditions.

However, the resources that have been identified as strategic assets in the literature are mainly based on physical resources and the capabilities of firms. In the current electronic marketspace, knowledge creation and innovation can make physical resources less important in the value creation activities of firms. Thus it is difficult for firms to gain competitive advantage through possession of physical resources since such resources can easily be copied by competitors. Therefore, strategic resources such as the creative employment of human capital, organisational learning and the internal and external network of relationships to the firm are becoming more important in the current electronic business environment. Among these resources, knowing the significance of network relationships is of primary importance considering their role in value creation in firms. The network relationships are 'relational assets' which are considered as intangible assets to firms 
$(22,43)$.

The literature which proposes a concept of 'relational assets' in international business emphasises the importance of relationships with stakeholders such as customers, suppliers, government sector organisations and trade associations. Thus the relationships with these organisations are important sources of competitive advantage since they can influence the business climate of the firm. These relational assets are recognised as intangible assets to firms in international business that contribute to enhance competitive advantage and performance $(44,53)$.

The RBV of the firm has been criticised for not providing enough explanation as to how and why certain firms maintain competitive advantage in unexpected and rapidly changing environments. Furthermore, it has been criticised for not paying attention to managerial abilities in using knowledge assets for the advantage of the firm $(34,47)$. In order to explain this, researchers have offered an extension of the RBV in the form of a 'dynamic capabilities' view of competitive strategy $(81,121)$. 'Dynamic capabilities' are defined as "the firm's ability to integrate, build, and reconfigure internal and external competences to address rapidly changing environments" (121). Thus capabilities of managers in responding to sudden changes in the environment push firms into competitive advantage in the global marketplace (121).

Madhok and Phene (88) suggest that the RBV with its base on performance of firms adds a valuable complement to the OLI paradigm arguing that differences exists between firms how they manage the current business environment. Taking the advantage of RBV, the firms ability to manage knowledge is proposed as the key source of firm-specific asset. Madhok and Phene (88) argue that this ability is tacit, causally ambiguous and difficult to copy as it is specific to the firm's activities. Thus they suggest that the firm should be considered as a sub-economy in its own right which emphasises the role of competitive advantage. This shows the need to integrate $\mathrm{O}$ advantage and I advantage of firms operating in the current business environment while creating synergies that increase $\mathrm{O}$ advantages of the firm in order to focus on firm-level capabilities compared to competitors $(87,88)$. Export marketing knowledge and experience, market information, business and social networks have also been recognised under the RBV of the firm as important elements that enhance the ownership advantages of the firm (118), which lead to competitive advantage.

The OLI paradigm focuses advantages that are unique to MNEs which can be used to increase the competitiveness in the targeted overseas market. It also discusses the advantages of the location which are specific to that market. As argued by Whitelock (127) the OLI paradigm suggests that the decision to enter foreign markets by MNEs is dependent to some extent on the information on the attraction of the overseas market. Thus, it appears that the market information is a pre-requisite of MNEs decision to internationalise. In contrast to this standard approach to internationalisation, the theory discuss next 'The Uppsala model' was developed based on the experiential knowledge as the primary indicator of market entry mode selection.

\subsection{The Uppsala Internationalisation Model}

The staged model of internationalisation, which is also known as the Uppsala internationalisation model was introduced by Johanson and Vahlne (73). It proposes that market entry or internationalisation is a gradual process. According to this theory, firms gradually increase their international commitment with the acquisition of market knowledge and experience. The purpose of this behaviour is to avoid risks that are involved in international marketing. The theory explains that in this gradual process firms adopt non-regular exports while having an independent local or foreign agent, sales subsidiary and local production. Furthermore, the international business activities of firms initially commence with markets that are culturally and geographically close, without substantially committing the firm's resources. The use of agents or direct selling is therefore practised in the first phase of internationalisation. The theory explains that once firms establish their exports with low risk, they will improve their foreign market knowledge. This knowledge gained through experience therefore leads the firms to increase exports with further expansion into distant markets. Doh (34) explains that the staged model is a complement to the theory of international competition introduced in 1966 as the international product life cycle model (PLC) of Vernon (124). The PLC model describes how MNEs receive the opportunity to export when capital intensive and technologically sophisticated products are initially developed in the USA for its own market and subsequently move into other developed and developing countries. However, the PLC theory was criticised by Cantwell (20) who stated that the model was not sophisticated enough to deal with the complex business environment and as many firms did not follow this process and showed a fast process of internationalisation instead $(34,94)$.

According to Gluckler (56) the 'OLI' and Uppsala model (Staged model) approach to a firm's internationalisation have gained more acceptance than other theories in international business. In analysing the theories of OLI and the staged model of internationalisation, Gluckler (56) highlights that, in both theories, firms compare potential markets in order to select the most appropriate. Hence, the market selection of the firm is based on the internal condition of the firm and market features. However, there is no empirical evidence which strongly supports these theories (56). Contrary to the above theories on foreign market entry, Westhead, Wright, Ucbasaran and Martin (126) argue, based on medium-sized manufacturing firms, that social networks and personal relationships are supportive for the actual choice of a target market suggesting the important role that social networks play in internationalisation. Similarly, 
Johanson and Vahlne (74) also in responding to the limitations of their staged model, support the network approach to internationalisation.

\subsection{The Network Approach to Internationalisation}

Therefore, in contrast to the internationalisation theories that have been discussed above, the network approach to internationalisation highlights external relations over internal conditions of the firm and its assets. Thus, the firm in a network leads to a specific strategic advantage in getting into foreign markets as it acts as a specific intangible asset (56). As argued by Sharma and Johanson (119) the international market entry is primarily dependent on a network position rather than other host market conditions such as economic or cultural conditions and they suggest that in the network approach, the firm's established relationships are part of a network for accessing resources which assists them in gaining new information at the right time. The relationships within the networks which function as bridges to unknown markets for firms emphasises social relationships as extremely important in internationalisation $(12,13,45,61,64,69,71,119)$. A number of existing empirical studies show that international market selection and foreign market entry are strongly influenced by existing client relations and business contacts (56).

Hakansson (60) describes the network approach as a natural choice for managers who use social networks over the years in order to increase power or get things done. Since the network is a product of interaction, the role of the individuals who are in the network for building trust is important to the development of these networks. Thus "the personal contacts are at the heart of interaction between organisations" (32) and they are "the medium in which communication takes place" (60). The individuals in networks can be part of professional associations, relatives, neighbours, even schoolmates, work place colleagues, social and sporting club members. Though these social networks are built up on personal relationships that are meant for different purposes, they can be used differently in order to develop business relationships (61). The firms in business networks are particularly in an advantageous position as there is pooling and combining of knowledge and skills of the individuals of the firm. The tacit knowledge which is unique to individuals and is developed based on individual experience is considered as main assets of firms. It is the network that such knowledge connects with other firms who are in a relationship $(61,102)$.

Johanson and Mattson (69) state the inter-firm relations perspective is an alternative approach to examine internationalisation of firms. Gluckler (56) argues that inter-firm approach to international expansion of firms is not different to the network approach as it proposes the function of external resources in facilitating the internationalisation of firms. This way of foreign market entry is explained as a result of gradually developing patterns of business relationships rather than logically derived most favourable applications $(14,56)$.

In the current state of an increasingly internationalised economy, many firms are motivated to expand their business to international markets. The conceptual approaches of the eclectic paradigm, the Uppsala staged theory and the network theory have been developed with the purpose of primarily explaining the internationalisation of MNEs. However, a firm's internationalisation seems difficult to explain using these theories because internationalisation is no longer limited to large firms but increasingly involves medium and small firms too. Thus many researchers have argued that the development of ICT, particularly the Internet, allows rapid internationalisation of firms which make them 'born global'. Hence the internationalisation of these firms displays a new process which cannot be explained by the traditional model of MNCs $(28,56,79)$.

Previous research found that exporters initially went through distinct stages in their internationalisation process described as an incremental pathway of internationalisation $(73,74)$. In the past, differences in language, culture and the slow speed of communication and transportation channels between countries have created difficulties in getting market information which therefore increased the risk of undertaking international business $(79,101,106)$.

The traditional way of internationalisation was a process in which a firm gradually increased the number and diversity of the markets they served. This staged model, which describes the traditional pathway, assumes that internationalisation activities develop incrementally over time and firms establish themselves domestically before entering international markets. The model further explains that firms chose export to the markets in close proximity before going into distant and culturally different markets in order to minimise the uncertainty involved in such markets where market knowledge is limited. It appears that the psychic distance is the major barrier and firms minimise this through experiential learning $(73,74)$. Large surveys of Finnish firms undertaken in the 1960s and 1970s by Luostarinen (86) supported the staged model. There are other research studies in support of positive correlation to indicate the relationship between export experience and export intensity as indicated in the literature reviews $(82,98)$.

Although this staged theory, which has focused on MNEs, gained general acceptance in academia since its development in 1970 s, several studies have questioned the validity of this internationalisation model because the increasing number of early internationalising firms brought challenges to the traditional models of internationalisation. The main argument has been that the traditional models were unable to explain the behaviour of firms that leapfrog or emerging phenomenon of 'born globals' which created a demand for new approaches to internationalisation $(1,31,51,79,97 ; 101,104,106,113,118)$. Andersen (1) argued that the ability of the staged model in explaining the boundaries between stages is limited. Studies on the 
relationship between firm size and export propensity are also ambiguous since some studies show a positive relationship, some no significant relationship and others argue that size matters (98). The literature on 'born globals' has shown the ability of small firms' rapid internationalisation. It is also shown that these firms either have completely ignored their home market while entering the international markets or chose to enter the home market and international market at once $(89,98)$.

\section{Born Globals}

The International business literature has historically focused on large and mature corporations. Many multinational enterprises (MNEs) are the developed form of large, mature domestic firms (26) which drew the attention of researchers with their significant economic power particularly after World War II. Large firms have long enjoyed major advantages over small firms since they have the resources to compete in export markets $(19,39,106)$. Nevertheless, in the current business environment, it is possible for a person who possesses international experience and a moderate amount of finance to conduct business anywhere in the world within a relatively short period. The ability to identify international business opportunities is therefore not limited to large corporations in the current business environment due to the advantages of low cost communication and transportation. Thus new firms with limited resources are able to successfully compete in international business (106).

Since the 1980s there has been a growing interest towards firms which do not follow the normal pattern of growing first in their home countries and then starting to export. Instead, these firms commence their exporting straight away or during the first years of their commencement. This sudden rise has brought about a new breed of exporters known as 'born globals' $(78,89,112)$, 'global start ups' (105), 'international new ventures' (94), 'high technology start-ups' (75). Reports appeared in the press and academic journals in the late 1980s and early 1990s about small firms internationalising from their inception or at an early days $(59,92,106,122)$. Literature shows that such firms are formed with internationally experienced business people who could link resources from multiple countries to meet the demand of markets. The ability of discovering and taking the advantage of international business opportunities are not only limited to large or mature corporations but firms with limited resources which can also compete successfully in international markets (93).

A survey conducted in 1993 by the United Nations found an increasing number of small firms found the stage by stage pattern of internationalisation no longer relevant to their needs, which is a limitation of the staged model. This was documented by the OECD (103) which reported that the time taken for business to internationalise has reduced from about ten years in the 1980s to about four or five years in the 1990s. Studies have found a large numbers of 'born globals' in Australia, the United States, Canada, Norway, France, and Denmark $(100,112)$.

The empirical study of Moen (100) involved small exporting firms from Norway and France found that more than $50 \%$ of the firms that had been formed after 1990 could be described as 'born globals'. This study revealed that the owners' or managers' global orientation is as one of the important factors responsible for this. The explanations given for the occurrence of this emerging phenomenon of 'born globals' is described by various trends that are taking place in the current business environment such as increasing trends of niche markets, advances in process technology, communication technology, the importance of international networks and alliances. The efficient use of transportation, more corporative government policies which have resulted in a decrease in geographically protected market niches are also suggested as reasons for the existence of 'born globals' $(78,95)$.

Andersson and Wictor (3) based on their research in Sweden found that the firms with the owners who could see the global opportunities what others cannot see have the ability to drive their firms to make 'born globals'. They suggest that the capable owners not only identify these opportunities but also use their personal networks both local and global as vital tools in implementing their strategies to become 'born globals'. The researchers suggest that theories that emphasis the vital role of internal resources such as the owner of the firm which add to the capabilities of such firms could provide better explanation to this phenomenon (3).

Knight and Cavusgil (79) based on their research in the US suggested early internationalisation related to innovative culture, knowledge and capabilities. The knowledge of the firm particularly works as a critical resource in the internationalisation process. Thus such firms are able to enhance their strategies from the use of knowledge based resources in winning business opportunities in international markets early in their evolution. The remarkable features of these born globals are that they commence with a global concept of their markets and build up the capabilities required in achieving the firm goals at the early stage of formation.

The smaller size distinctive of young firms appears to present a kind of flexibility that provides key benefits for succeeding in overseas markets. The argument here is that the bureaucratic nature of large and long-established firms tends to block their innovativeness. The less bureaucratic small and young firms with their more flexible nature tend to encourage the innovativeness of the firm. This innovativeness of the firm assists the development of firm specific knowledge and capabilities that enhances firm performance with market expansion. The flexibility of small and active firms takes this advantage to gain superior business performance by transforming their innovations into business functions $(79,83)$. Knight and Cavusgil (79) present 
an explanation for 'born globals' taking support from the RBV of the firm. Their explanation suggests that the firm's resources are primarily important to develop strategies of the firm which suits diverse business environments. Thus it is the function of the internationally focused managers of newly formed small firms to develop unique and inimitable knowledge. This knowledge assists them in enhancing the superior international performance. Thus Knight and Cavusgil (79) argue that this special knowledge creates the required firm capabilities. Such capabilities carry the potential to be part of the firm culture which can also be tacit or inimitable to the firm $(4,6,58)$. It is suggested that technology, ICT in particular facilitate the marketing process of 'born globals' learning about customers, competitors and efficient channel interaction (79).

It is observed in a research study in Austria, the Czech Republic and Slovenia that firms need to receive cross-boarder cooperation with overseas partners for access to their resources in order to overcome the insurmountable financial difficulties that they have to confront in the process of internationalisation. The outcome of the research showed that development of trust-based cooperation relationships with foreign firms works positively for small firm internationalisation. The owners' or managers' self-commitment was vital in developing this cooperative relationship and it was advantaged by their psychic closeness to their export markets. Mutual trust and commitment were based on common long-term business goals rather than short-term plans that encourage early defection. This helped firms in business to maintain sustainable trust-based cooperation relationships with a minimum business conflicts $(50,53)$.

Thus Fink and Kraus (50) argue that firms in this form of relationship could grow uninterruptedly together and it further makes firm activities easy and helps them to save resources. Fink and Kraus (50) also provide examples from Japan of trust-based relationships such as 'Kairetsu'. They advise that firms must harness the advantages of stable, long-term business relationships which carry a minimum level of conflict. The Japanese concept of 'Kyosei' could also ensure owner/managers of firms take lessons in business diplomacy and responsibility for themselves and others while keeping to entrepreneurial attitudes and make profits. Diplomacy assists in business to build trust and develop relationships which is considered the key to long-term sustainable success $(76,85)$.

Galbreath (53) argues that the power of the key relationships in firms supersedes the power of information because such relationships are myriad in nature as they are rooted to many entities of the business climate the firm operates. All of these relationships are in a complex network though they are mutually interdependent. Thus successful firms take appropriate measures in order to maintain healthy relationship networks with the aim of building trust. These are firms which build barriers to exit by creating mutual trust and respect within the firm's myriad relationships. Such relationships could provide long-term benefits even though they take time and resources to build. Fink and Kraus (50) state that identification of management tools and factors that encourage such relationships have been marked as critically important in future investigations.

Small firms heavily rely on niche markets in their exporting process and most of the learning in this process results from being linked to information networks both at home and overseas markets. Internet technology plays a major role in getting access to appropriate contacts abroad thereby assisting the small firms to overcome the disadvantage of small size (78). Although the OLI paradigm, the born global and network perspectives are considered the most recent theories of internationalisation, the relevance of the OLI paradigm to small firm appears to be limited. The reason is that the OLI paradigm is applicable to MNEs which carry three types of advantages namely ownership, location and internalisation due to their multinational nature.

The role of networks in firm internationalisation has also drawn special attention particularly in explaining internationalisation of small firms. The reason is that the network perspective on internationalisation can also provide the opportunity to understand how it could help the resourced limited small firms enter into foreign markets (118). As explained under 'Market entry modes in IB', the network perspective suggests that internationalisation process is assisted by networks of relationships (70). It is suggested by Rutashobya and Jaensson (118) also that social capital, human variables and trust have important role in building value adding relationships between these firms. These relationships assist small firms to overcome their disadvantages such as small size and isolation. They also help in overcoming the difficulties that may involve lack of market knowledge and psychic distance.

These networks of people who trust and help each other in a relationship are considered important assets particularly to resource-limited, small firms as they can assist in reaching vital information. These relationship assets are grounded in both the resource-based view of the firm and the relationship marketing paradigm $(6,65)$. According to Premaratne (111), networks can be identified as social, supporting and inter-firm. For example,

- Social: relatives and friends

- Supporting: banks and government agencies

- Inter-firm: clients, suppliers, organisational networks

Although the findings of Bell (10) suggest that internationalisation of small firms may be influenced by inter-firm relationships, other literature suggests that social networks provide better and stable resources to small firms than inter-organisational networks. In brief, the information that is accessed through networks is not only useful in identifying new business opportunities but also in promoting the success of existing businesses and their growth. Thus, it is argued that having access to networks could provide small firms with the necessary resources to successfully face competition $(55,69,111)$. 


\section{Conclusions}

The purpose of this paper was to critically analyse the theories of International Business (IB) and gain a clear understanding of the influence of information and communication technologies (ICTs) on existing theories of IB. In order to achieve this purpose, the basics of IB and current trends in the IB environment affecting firm internationalisation was analysed and discussed in detail.

This paper has initially reviewed the vital literature on international business (IB) and observed that mode of foreign market entry of firms is the way of understanding IB. The review highlights that among the main entry mode theories discussed in this paper, the Eclectic paradigm, the Staged model and the Network approach are prominently used in explaining firm internationalisation.

However, the Eclectic paradigm and the Staged model approach to the firm internationalisation were criticized for considering only the internal factors of the firm and market features for selecting markets, ignoring the factors that are external to the firm. The network approach highlights the role of external networks in the form of social, supporting and inter-firm networks affecting the internationalisation of firms. Thus the theory emphasizes external relations over internal conditions of the firm and its assets. It explains how relationships assist firms in gaining new information at the right time. There is research evidence to support the utility of this theory. The information that is accessed through networks is not only useful in identifying new business opportunities but also in promoting the success of the existing businesses and their growth.

Nevertheless, these theories have developed with the purpose of primarily explaining the internationalisation of large MNEs. The review provides evidence that a firm's internationalisation is not limited to those large MNEs but increasingly smaller firms are engaging in international business. Internationalisation of these firms has been a rapid process which can not be explained by the above internationalisation theories and so researchers have looked to ICTs, particularly the Internet, as a factor contributing to rapid internationalisation and being 'born global'.

Some of the other factors that seem to contribute to this phenomenon worldwide in general are the increasing trends of niche markets, advances in process technology, capabilities of owner/managers of firms and increased importance of networks. In addition, the efficient use of transportation and more supportive government policies in the form of trade facilitation have also been suggested as contributing to the current trend of 'born global'. However the analysis indicates that only a limited number of research has been undertaken in a few number of countries in this respect. Hence need for further research in multiple countries is suggested in order to gain better understanding of the factors that contribute to the 'born global' phenomenon.

The network perspective suggests that the internationalisation process is assisted by networks of relationships which are useful to the resource-limited small firms in entering foreign markets. These networks have been identified as social, supporting and inter-firm. The relationships are considered as important assets to small firms as the external networks can assist in reaching vital information. Trust has an important role in building value adding relationships between firms which assist small firms to overcome their difficulties and disadvantages. The owner/manager's commitment is vital in developing this relationship.

The literature review provided evidence that a firm's internationalisation is not limited to those large MNEs but increasingly smaller firms are engaging in international business. The review also indicates that exporting is the main form of doing international business for small firms' and is an alternative to other market entry modes used by large MNEs with their $\mathrm{O}$ advantage. It was observed that exporting is a comparatively low risk taking form of doing international business to small firms considering the lower financial commitment involved.

Internationalisation of these firms has been a rapid process and ICT, particularly the Internet, has been suggested as a factor contributing to their rapid internationalisation. However, the influence of the Internet for their performance is not known. Thus, given the importance in exporting and ICT particularly the Internet into small firm internationalisation, it is suggested that future research should be focused on understanding the role of ICT in the performance of exporting firms.

\section{REFERENCES}

[1] O. Andersen. On the Internationalisation process of firms: A critical analysis, Journal of International Business Studies, Vol. 24, No.2, 209-230, 1993

[2] E. Anderson, H. Gatignon. Modes of foreign entry: A transaction cost analysis and propositions, Journal of International Business Studies, Vol. 17, No.3, 1-26, 1986.

[3] S. Andersson, I. Wictor. Innovative internationalisation in new firms: born globals-the Swedish case, Journal of International Entrepreneurship, Vol. 1, No.3, 249-275, 2003.

[4] E. Autio, H. Sapienza, J. Almeida. Effects of age at entry, knowledge intensity and imitability on international growth, Academy of Management Journal, Vol. 43, No.5, 909-1014, 2000.

[5] J. Barney, Organisational culture: can it be a source of sustained competitive advantage?, Academy of Management Review, Vol. 11, No. 3, 656-665, 1986.

[6] J. Barney, (1991), Firm resources and sustained competitive advantage, Journal of Management, Vol. 17, No.1, 99-120, 1991.

[7] J. Barney. Looking inside for competitive advantage, Academy of Management Executive, Vol. 9, No. 4, pp. 49-61, 1995. 
[8] J. Barney. Gaining and Sustaining Competitive Advantage, Mass: Addison-Wesley Publishing Company, Inc., Reading, 1997.

[9] Barney, J.B., Is the resource-based 'view' a useful perspective for strategic management research? Yes, Academy of Management Review, Vol. 26, Issue 1, 41-56, 2001.

[10] J. Bell. The internationalisation of small computer software firms: a further challenge to 'Stage' theories, European Journal of Marketing, Vol. 29, No. 8, 60-75, 1995.

[11] S. G. Bharadwaj, P. R. Varadarajan, J. Fahy. Sustainable competitive advantage in service industries: a conceptual model and research propositions, Journal of Marketing, Vol. 57, No. 4, 83-99, 1993.

[12] I. Bjorkman, S. Kock. Social relationships and business networks: the case of Western Companies in China, International Business Review, Vol. 4, No. 4, 519-535, 1995.

[13] D. Blankenburg. A Network Approach to foreign market entry, in Business Marketing: An Interaction and Network Perspective, eds. K. Moller and D. Wilson, Kluwer Academic Publishers, Boston, 1995.

[14] D. Blankenburg, K. Eriksson, J. Johanson. Business networks and cooperation in international business relationships", Journal of International Business Studies, Vol. 5, 1033-1053, 1996.

[15] J. J. Boddewyn, G. Iyer. International Business Research: Beyond Deja Vu, Management International Review, Vol. 39, 164-245, 1999.

[16] L. E. Brouthers, K. D. Brouthers, S. Werner. Is Dunning's eclectic framework descriptive or normative, Journal of International Business Studies, Vol. 30, No. 4, 831-844, 1999.

[17] P. J. Buckley. A critical view of theories of the multinational enterprise, in P. J. Buckley and M. Casson (eds.), pp. 1-19, The Economic Theory of Multinational Enterprise. London: The Macmillan Press, 1985.

[18] P. J. Buckley. Is the international business research agenda running out of steam?, Journal of International Business Studies, Vol. 33, No. 2, 365-373, 2002.

[19] P. J. Buckley, M. Casson. The Future of the Multinational Enterprise, Macmillan, London, 1976.

[20] Cantwell, J. The globalisation of technology: what remains of the product life cycle model?, Cambridge Journal of Economics, Vol. 19, No. 1, 155-230, 1995.

[21] J. Cantwell, R. Narula. The eclectic paradigm in the global economy, International Journal of the Economics of Business, Vol. 8, No. 2, 155-172, 2001.

[22] S. Cartwright, R. Oliver, R. Untangling the value web, Journal of Business Strategy, Vol. 21, No. 1, 22-27, 2000.

[23] M. Casson, Transaction costs and the theory of the multinational enterprise, in New theories of the Multinational Enterprise, ed. A.M. Rugman, Croom Helm, London, 1982.

[24] R. F. Caves. International Corporations: The Industrial Economics of Foreign Investment, Economica, Vol. 38, 1-27, 1971.

[25] R. E. Caves. Multinational Enterprises and Economic Analysis, Cambridge University Press, New York, 1982.
[26] A. D. Chandler. 'The evolution of modern global competition', in M. E. Porter (ed.), Competition in global industries, Harvard Business School Press, Boston, 1986.

[27] S. Chatterjee, B. Wernerfelt. The link between resources and type of diversification: theory and evidence, Strategic Management Journal, Vol. 12, No. 1, 33-48, 1991.

[28] P. Chetty. A strategic approach to internationalization: a traditional versus a 'born-global' approach, Journal of International Marketing, Vol. 12, 57-81, 2004.

[29] V. Clulow, J. Gerstman, C. Barry. The resource-based view and sustainable competitive advantage: the case of a financial services firm, Journal of European Industrial Training, Vol. 7, No. 5, 220-252, 2003.

[30] D. J. Collis. A resource-based analysis of global competition: the case of the bearings industry, Strategic Management Journal, Vol. 12, Special issue, 49-68, 1991.

[31] N. E. Coviello, H. J. Munro. Growing the entrepreneurial firm: Networking for international market development, European Journal of Marketing, Vol. 29, 7, 49-61, 1995.

[32] M. T. Cunningham, P. W. Turnbull. Inter-organisational personal contact patterns, in International Marketing and Purchasing of Industrial Goods, eds. H. Hakansson, John Wiley, Chichester, 1982.

[33] M. R. Czinkota, P. Rivoli, I. A. Ronkainen. International Business (2nd ed.), The Dryden Press, Orlando, FL, 1992.

[34] J. P. Doh, (2005), Offshore outsourcing: implications for international business and strategic management theory and practice, Journal of Management Studies, Vol. 42, No. 3, 695-704, 2005.

[35] W. M. Dugger. The Transaction Cost Analysis of Oliver, E. William: A New Synthesis?, Journal of Economic Issues, Vol. XVLL, No. 1, 95 - 114, 1983.

[36] J. H. Dunning, The determinants of international production, Oxford Economic Papers, Vol. 25, 289-336, 1973.

[37] J. H. Dunning. Trade, location of economic activity and the MNE: a search for an eclectic approach, in The International Allocation of Economic Activity, eds. B. Ohlin, P. Hesselborn, P. Wijkman, Macmillan, London, 1977.

[38] J. H. Dunning. Explaining changing patterns of international production: a search for the eclectic theory, Oxford Bulletin of Economics and Statistics, Vol. 161, 269-295, 1979.

[39] J. H. Dunning. International Production and the Multinational Enterprise, Allen and Unwin, London, 1981.

[40] J. H. Dunning. The eclectic paradigm of international production: A restatement and some possible extensions, Journal of International Business Studies, Vol. 19, No.1, 1-31, 1988.

[41] J. H. Dunning. Repairing the Electric Paradigm in the Age of Alliance Capitalism, Journal of International Business Studies, Vol. 26, No. 3, 461-493, 1995.

[42] J. H. Dunning. The eclectic paradigm as an envelope for economic and business theories of MNE activity, International Business Review, Vol. 9, 163-190, 2000. 
[43] J. H. Dunning, C. Wymbs. The Challenge of Electronic Markets for International Business Theory, International Journal of the Economics of Business, Vol. 8, No. 2, 273-301, 2001.

[44] J. H. Dunning. Relational assets, networks and international business activity, in Alliance Capitalism and Corporate Management: Entrepreneurial Cooperation in Knowledge Based Economies, eds. J. H. Dunning and G. Boyd, Edward Elgar, Cheltenham, 2003.

[45] G. Easton, L. Araujo. Characterising organizational competences: an industrial network approach, in Dynamics of Competence-Based Competition, eds. R. Sanchez., A. Heene and H. Thomas, Oxford: Elsevier, Oxford, 1996.

[46] M. K. Erramilli, S. Agarwal, S. Kim. Are Firm-Specific Advantages Location-Specific Too?, Journal of International Business Studies, Vol. 28, No. 4, 735 - 757, 1997.

[47] K. M. Eisenhardt, J. A. Martin. Dynamic capabilities: what are they?, Strategic Management Journal, Vol. 21, No. 10/11, 1105-1121, 2000.

[48] M. K. Erramilli, P. C. Rao. (1993), Service firms' international entry-mode choice: A modified transaction-cost analysis approach, Journal of Marketing, Vol. 57, No. 3, 19-38, 1993.

[49] J. Fahy. The resource-based view of the firm: some stumbling-blocks on the road to understanding sustainable competitive advantage, Journal of European Industrial Training, Vol. 24, No. 2, 94-104, 2000.

[50] M. Fink, S. Kraus. Mutual trust as a key to internationalisation of SMEs, Management Research News, Vol. 30, No. 9, 674-688, 2007.

[51] R. A. Fletcher. A holistic approach to internationalisation, International Business Review, Vol. 10, 25-49, 2001.

[52] L. G. Franko. Joint Venture Survival in Multinational Corporations, Praeger Publisher, New York, 1971.

[53] J. Galbreath. Success in the relationship age: building quality relationship assets for market value creation, The TQM Magazine, Vol. 14, No.1, 8-24, 2002.

[54] G. Gemser, M. J. Brand, A. Sorge. Exploring the internationalisation process of small business: a study of Dutch old and new economy firms, Management International Review, Vol. 44, No. 2, 127-177, 2004.

[55] S. Ghoshal, C. Bartlett. The multinational corporation as an interorganisational network, Academy of Management Review, Vol. 15, No. 4, 603-628, 1990.

[56] A. A. Gibb, Key factors in the design of policy support for the small and medium enterprise (SME) development process: an overview, Entrepreneurship and Regional Development, Vol. 7, 1-24, 1993

[57] J. Gluckler. A relational assessment of international market entry in management consulting, Journal of Economic Geography, Vol. 6, No. 3, 369-393, 2006.

[58] R. M. Grant, R. M. Prospering in dynamically-competitive environments: Organisational capability as knowledge integration, Organisation Science, Vol. 7, No. 4, 375-387, 1996.
[59] R. M. Grant, Toward a knowledge-based theory of the firm, Strategic Management Journal, Vol. 17, Winter Special Issue, 109-122, 1996.

[60] U. Gupta. Small firms aren't waiting to grow up to go global, The Wall Street Journal, December 5: B2, 1989.

[61] H. Hakansson. Industrial Technological Development: a network approach, Croom Helm, Sydney, 1987.

[62] H. Hakansson, I. Snehota. Developing Relationships in Business Networks, Routledge, London, 1995.

[63] K. R. Harrigan. Strategic Flexibility: A Management Guide for Changing Times, Lexington, Lexington, Mass: Lexington, 1985.

[64] J. Hennart. The transaction costs theory of joint ventures: an empirical study of Japanese subsidiaries in the United States, Management Science, Vol. 37, No. 4, 483 - 497, 1991.

[65] S. Hinttu, M. Forsman, S. Kock. Mission Impossible Internationalisation without Social Networks, in Handbook of research on international entrepreneurship, ed. L. P. Dana, Edward Elgar, Cheltenham, 2004.

[66] S. D. Hunt, R. M. Morgan. The comparative advantage theory of competition, Journal of Marketing, Vol. 59, No. 2, 1-15, 1995.

[67] S. H. Hymer. The International Operation of National Firms: A study of direct foreign investment, Cambridge, MA: MIT Press, 1976.

[68] F. Jiang. International pharmaceutical firms' market entry modes decisions into China: a comparison between early-entrants and late-entrants", Journal of Academy of Business and Economics, Vol. 2, No. 2, 6-13, 2003.

[69] F. Jiang, C. Christodoulou, H. C. Wei, The determinants of international pharmaceutical firms' FDI in China: a comparison between early (pre-1992) and late (from-1992) entrants, Management Decision, Vol. 39, No. 1, 45-56, 2001.

[70] J. Johanson, L. G. Mattsson. Inter-Organisational Relations in Industrial Systems: A Network Approach Compared with the Transaction-Cost Approach, International Studies of Management and Organisations, Vol. 17, No. 1, 34-48, 1987.

[71] J. Johanson, L. G Mattsson (1988), Internationalization in industrial systems-a network approach, in Strategies in Global Competition, eds. N. Hood and J. E. Vahlne, Croon Helm, London, 1988.

[72] J. Johanson, L. G. Mattsson. The markets as networks tradition in Sweden, in Research Traditions in Marketing, Ed., Laurent, G., Gary, L. L. and Pras, B., Kluwer Academic Publishers, Boston, MA, 1994

[73] J. Johanson, L. G. Mattsson. International marketing and internationalisation processes: a network approach, in International Marketing Reader, eds. S. J. Paliwoda and J. K. Ryans, Routledge, London, 1995.

[74] Johanson, J. and Vahlne, J. E. The internationalisation process of the firm: a model of knowledge development and increasing foreign market commitment", Journal of International Business Studies, Vol. 8, No. 1, 23-32, 1977.

[75] J. Johanson, J. E. Vahlne. The mechanism of internationalisation, International Marketing Review, Vol. 7, $11-24,1990$. 
[76] V. K. Jolly, M. Alahuhta, J. P. Jeannet. Challenging the incumbents: How high technology start-ups compete globally, Journal of Strategic Change, Vol. 1, 71-82, 1992.

[77] R. Kaku. "Kyosei" in Corporate Diplomacy: principled leadership for the global community, eds. R. Trice., M. Hasegawa and M. Kearns, The Centre for Strategic and International Studies, Washington, DC, 1995.

[78] C. P. Kindleberger. American Business Abroad: Six Lectures on Direct Investment, Yale University Press, New Haven, 1969.

[79] G. A. Knight, S. T. Cavusgil. The born global firm: A challenge to traditional internationalisation theory, Advances in International Marketing, Vol. 8, 11-26, 1996.

[80] G. A. Knight, S. T. Cavusgil. Innovation, organisational capabilities, and the born-global firm, Journal of International Business Studies, Vol.35, No. 2, 124-141, 2004.

[81] B. Kogut. Joint Ventures: Theoretical and Empirical Perspectives, Strategic Management Journal, Vol. 9, Issue 4, 319-332, 1988.

[82] B. Kogut, U. Zander. Knowledge of the firm, combinative capabilities, and the replication of technology, Organization Science, Vol. 3, 383-397, 1992.

[83] L. C. Leonidou, C. S. Katsikeas. The export development process: an integrative review of empirical models, Journal of International Business Studies, Vol. 27, No. 3, 517-552, 1996.

[84] A. Y. Lewin, S. Massini. Knowledge creation and organisational capabilities of innovating and imitating firms", in Organisations as Knowledge Systems, eds. H. Tsoukas and N. Mylonopoulos, Palgrave, Basingstoke, 2003.

[85] F. Li, J. Li. Foreign Investment in China, St. Martin's Press, New York, 1999.

[86] M. London. Principled leadership and business diplomacy: A practical, values-based direction for management development, Journal of Management Development, Vol. 18, No. 2, 170-192, 1999.

[87] R. Luostarinen, Internationalization of the firm: An empirical study of the internationalization of firms with small and open domestic markets with special emphasis on lateral rigidity as a behavioural characteristic in strategic decision-making, The Helsinki School of Economics, Helsinki, 1979.

[88] A. Madhok, T. Osegowitsch. The International biotechnology industry: a dynamic capabilities perspective, Journal of International Business Studies, Vol. 31, 325-331, 2000.

[89] A. Madhok, A. Phene. The Co-evolutional advantage: strategic management theory and the eclectic paradigm", International Journal of the Economics of Business, Vol. 8, No. 2, 243-256, 2001.

[90] T. K. Madsen, P. Servais. The internationalisation of born globals: an evolutionary process?, International Business Review, Vol. 6, No. 6, 561-583, 1997.

[91] R. Maier. Knowledge Management Systems: Information and Communication Technologies for Knowledge Management, 2nd edition, Springer, Berlin, 2004.

[92] S. Makino, A. Delios. Local Knowledge Transfer and Performance: Implications for Alliance Formation in Asia,
Journal of International Business Studies, Vol. 27, No. 5, 905-927, 1996.

[93] R. A. Mamis. 'Global start-up' Inc., August, Vol. 11, No. 8, 38-47, 1989.

[94] P. P. McDougall, M. Oviatt. Global start-ups: New ventures without geographic limits, The Entrepreneurship Forum, Winter: 1-5, 1991.

[95] P. McDougall, S. Shane, B. M. Oviatt. Explaining the formation of international new ventures: The limits of theories from international business research, Journal of Business Venturing, Vol. 9, 469-487, 1994.

[96] P. P. McDougall, B. M. Oviatt. International Entrepreneurship: The Intersection of Two Research Paths, Academy of Management Journal, Vol. 43, no. 5, 902-906, 2000.

[97] J. McManus. The theory of international firm, in The Multinational firm and the nation state, ed. G. Paquet, Macmillan, Toronto, 1972.

[98] R. B. McNaughton. Determinants of Time-Span to Foreign Market Entry: Evidence from Canadian Micro-Businesses, Journal of Euro Marketing, Vol. 9, No. 2, 99-112, 2000.

[99] R. B. McNaughton. The number of export markets that a firm serves: process models verses the born-global phenomenon, Journal of International Entrepreneurship, Vol. 1, 297-311, 2003.

[100] P. Meso, R. Smith. A resource-based view of organisational knowledge management systems, Journal of Knowledge Management, Vol. 4, No.3, 224-258, 2000.

[101] O. Moen. The born globals: A new generation of small European exporters, International Marketing Review, Vol. 19, No. 2/3, 156-175, 2002.

[102] O. Moen, P. Servais. Born global or gradual global? Examining the export behaviour of small and medium-sized enterprises, Journal of International Marketing, Vol. 10, No. 3, 49-72, 2002.

[103] I. Nonaka. The knowledge-creating company", Harvard Business Review, Vol. 69, No. 6, 96-104, 1991.

[104] OECD, Globalisation and Small and Medium Enterprises, OECD, Paris, 1997.

[105] M. J. Oesterle. Time span until internationalisation: foreign market entry as a built-in mechanism of innovation, Management International Review, Vol. 37, No.2, 125-149, 1997.

[106] B. M. Oviatt. and P. P. McDougall. Toward a theory of international new ventures, Journal of International Business Studies, Vol. 25, No. 1, 45-64, 1994.

[107] B. M. Oviatt, P. McDougall. Toward a theory of international new ventures, Journal of International Business Studies, Vol. 36, 29-41, 2005.

[108] S. A. Ozga. Imperfect Markets through Lack of Knowledge, The Quarterly Journal of Economics, Vol. 74, No. 1, 29-52, 1960.

[109] T. G. Parry. The Multinational Enterprise: International Investment and Host Country Impacts. Greenwich: Jai Press, 1980. 
[110]E. T. Penrose. The Theory of the Growth of the Firm, John Wiley, New York, 1959.

[111] M. A. Peteraf. The cornerstones of competitive advantage: A resource-based view, Strategic Management Journal, Vol. 14, No.3, 179-191, 1993.

[112] S. P. Premaratne, Networks, resources, and small business growth: the experience in Sri Lanka, Journal of Small Business Management, Vol. 39, No. 4, 363-372, 2001.

[113] M. W. Rennie, Global competitiveness: born global, McKinsey Quarterly, No. 4, 45-52, 1993.

[114] A. Rialp, J. Rialp, G. A. Knight. The phenomenon of early internationalizing firms: what do we know after a decade (1993-2003) of scientific inquiry?", International Business Review, No. 14, No. 2, 147-166, 2005.

[115]F. R. Root. Entry strategies for international markets, Lexington Books, Mass, 1987.

[116]F. R. Root. Entry strategies for international markets, Lexington Books, New York, 1994.

[117] A. M. Rugman. (1980), Internalization as a general theory of foreign direct investment: A re-appraisal of the literature, Review of World Economics, Vol. 116, Issue 2, 365 - 379, 1980.

[118] A. M. Rugman. New Theories of the Multinational Enterprise, London: Croom Helm, 1982.

[119] L. Rutashobya, J. Jaensson. Small firms' internationalisation for development in Tanzania: exploring the network phenomenon, International Journal of Social Economics, Vol. 31, No. 1/2, 159-172, 2004.

[120] D. D. Sharma, J. Johanson. Technical consultancy in internationalisation, International Marketing Review, Vol. 4, No. 4, 20-29, 1987.

[121] J. M. Stopford, and L. T. Wells Jr. Managing the MNE: Organisation of the firm and ownership of the subsidiaries, Basic Books, New York, 1972.

[122] D. J. Teece, G. Pisano, A. Shuen. (1997), Dynamic capabilities and strategic management, Strategic Management Journal, Vol. 18, 509-533, 1997.

[123] The Economist, America's little fellows surge ahead, July 3, 59-60, 1993.
[124] P. E. Tolentino. From a theory to a paradigm: examining the eclectic paradigm as a framework in international economics, International Journal of the Economics of Business, Vol. 8, No. 2, 191-209, 2001.

[125] R. Vernon. International investment and international trade in the product life cycle, Quartely Journal of Economics, Vol. 80, 190-207, 1966.

[126] B. Wernefelt. A resource-based view of the firm, Strategic Management Journal, Vol. 5, No. 2, 171-181, 1984.

[127] P. Westhead, M. Wright, D. Ucbasaran, F. Martin. International market selection strategies of manufacturing and services firms, Entrepreneurship \& Regional Development, Vol. 13, 17-46, 2001 .

[128] J. Whitelock. Theories of internationalisation and their impact on market entry, International Marketing Review, Vol. 19, No. 4, 342-347, 2002.

[129] A. Wilcox-King, C. P. Zeithmal. Competencies and firm performance: Examining the causal ambiguity paradox, Strategic Management Journal, Vol. 22, No. 1, 75-99, 2001.

[130] O. E. Williamson. Markets and Hierarchies: Analysis \& Antitrust Implications, Prentice-Hall, Englewood Cliffs, N. J, 1975.

[131] O. E. Williamson. The economics of organisation: the transaction cost approach; American Journal of Sociology, Vol. 87, No. 3, 548-577, 1981.

[132] P. M. Wright, B. B. Dunford, S. A. Snell, Human resources and the resource based view of the firm, Journal of Management, Vol. 27, 701-721, 2001.

[133] Y. Wu. FDI and economic growth: an introduction, in Foreign Direct Investment and Economic Growth in China, ed. Y. Wu, Edward Elgar, Cheltenham, 1999.

[134] S. Young, J. Hamill, C. Wheeler, J. R. Davies. International Market Entry and Development, Englewood Cliffs, NJ: Prentice Hall, 1989.

[135]X. Zhang, H. P. Yuk. Determinants of Hong Kong manufacturing investment in China: a survey, Marketing Intelligence and Planning, Vol. 16, No. 4, 260-267, 1998. 